\title{
Effectiveness of a diabetes educational intervention at primary school
}

\author{
Denise Machado Mourão ${ }^{1}\left[\right.$. Bruna Martins Grassi Sedlmaier ${ }^{1}\left[\right.$ Victor Luiz Rocha Pires $^{1}(\mathbb{D} \cdot$ \\ Grasiely Faccin Borges ${ }^{2}$ (])
}

Received: 21 July 2021 / Accepted: 11 November 2021 / Published online: 21 January 2022

(c) The Author(s), under exclusive licence to Research Society for Study of Diabetes in India 2021

\begin{abstract}
Background Brazil ranks fifth in the world in the number of adults with diabetes, and third for type 1 diabetes. Conducting educational actions on this topic in public schools in this country is extremely important, since it can assist in the early adoption of good life habits and in a better care for students in this condition.

Objective The aim of this study was to assess the effectiveness of an educational intervention about diabetes for students and school staff.

Methods This is an interventional non-randomized longitudinal study, in which interviews were conducted before and after a playful intervention with the use of theater play and games for students and plus a training for the school staff.

Results A total of 89 participants completed the study, being 73 students aged 7 to 12 years old, and 16 school staff. As a result, there was a positive change in knowledge and perception of diabetes by the students. The greatest changes in the answers among the participants, at the post-intervention period, were related to the possibility of consuming something with sugar by those with diabetes, and particularly how to cope in hypoglycemia situations by the school staff.

Conclusions Actions like these must be encouraged within the school environment, especially in countries with high prevalence of diabetes.
\end{abstract}

Keywords Diabetes mellitus $\cdot$ Health education $\cdot$ School health services $\cdot$ Primary school $\cdot$ Community networks

\section{Introduction}

Promoting health education in public schools in Brazil is an extremely important challenge, since it allows for the early adoption of good life habits and helps the school staff to take better care for their students. One in eleven people in the world has diabetes mellitus (DM) and, although type 1 (T1DM) is one of the most common chronic disease in childhood, type 2 (T2DM) is also increasing considerably in older children and adolescents, due to the increase in overweight and obesity in these population groups [1].

Some attitudes reflect the level of knowledge on diabetes $[2,3]$, so family members of affected children are constantly concerned about the management of this condition in the

Denise Machado Mourão

denise.mourao@cpf.ufsb.edu.br

1 Health Science Center, Federal University of Southern Bahia, Teixeira de Freitas, Bahia, Brazil

2 Public Policies and Social Technologies Center, Federal University of Southern Bahia, Itabuna, Bahia, Brazil schools, as they recognize lack of preparedness in the school staff regarding support for self-care [4, 5], and classmates help [6]. In this way, a recent systematic review has shown association between bullying and T1DM when compared to individuals with no such condition in public environments, such as school [6].

The Children and Diabetes in Schools (KiDS) program has been used in several countries to promote diabetes education in the schools [7]. In Brazil, it was implemented in 2014 [6], being one of the basic tools used by the Diabetes Reference Centers in schools in the country [8, 9]. In addition to the KiDS educational package, it is recommended to use an interactive methodology in the schools, such as training with the school staff $[8,9]$, and/or playful actions with the students [10].

The use of performing arts, specifically theater play, has been shown to be very efficient for children and youth audiences [10-12]. In Brazil, few studies used theater play as a playful tool for diabetes education in schools, although without assessing the change in the participants' level of knowledge after its application [11, 12]. 
When considering that children and adolescents can spend more than $30 \mathrm{~h}$ per week in the school environment [13], that there will be a probable $50 \%$ increase in the number of DM cases by 2040 [1], and that diabetes education is a fundamental component of the treatment [14] as well as for the prevention of T2DM, it is necessary to adopt efficient educational practices in the schools. In this way, the aim of this study was to assess the effectiveness of using a playful intervention, associated with other tools in diabetes education for students and school staff.

\section{Materials and methods}

\section{Design}

This is an interventional non-randomized longitudinal study design (pre- and post-intervention) carried out in a public Primary Education School in Teixeira de Freitas, Bahia, Brazil. The school staff and the students were invited to participate in this study at the school, after presentation by the researchers, in addition to sending an invitation letter to the guardians.

\section{Sampling and research team}

The sample of the study was a non-probabilistic one, with students from second to the fifth grade were included and school staff. In the data collection period, the school had a total of 238 students enrolled, of which 186 were between second and fifth grade, and 21 employees (10 teachers, five general service assistants, two teaching assistants, a principal and a vice director, a secretary, and an administrative assistant).

The inclusion criteria were as follows: Students: being enrolled from second to fifth grade of primary school, attending classes regularly; School staff: being part of the school permanent team. The exclusion criteria for students and employees were as follows: not accepting to participate in the study, not being present at the time of data collection, and, also for students, not having signed the Assent Form or not having the Free and Informed Consent Form signed by one of the guardians. In the pre-intervention interviews, 83 students and 19 members of the school staff participated, and in the post-intervention interviews, 73 students and 16 members of the school staff participated of the study.

The entire study was conducted by members of the Diabetes Reference Center in the Schools of Teixeira de Freitas (CRDE-TxF), by students and professors from the courses of Medicine, Psychology and Interdisciplinary Bachelor's Degree in Health of the Federal University of Southern Bahia (UFSB).

\section{Study procedure}

To check the participants' knowledge and perception of diabetes, a one-on-one face-to-face structured interview was examined twice for each participant, before and after intervention. To promote diabetes education, an intervention was conducted in the form of a theater play for the entire school community. Two days later, the school staff also had a training course. Finally, 2 months after the intervention, the same interview was re-applied in the same sample group (school staff and students), to verify changes in perception based on the educational actions. The methodological path of the study is shown in Fig. 1.

\section{Interview and data collection}

A reserved room was used for the one-on-one face-to-face structured interviews, between October and December 2019. The questions used were elaborated by the CRDE-TxF team itself, based on a review literature and on KiDS educational package [15]. For the students, 20 questions were used to assess diabetes general perceptions, signs and symptoms of hypoglycemia and hyperglycemia, and diet and diabetes management at school. For the school staff, 24 questions were used, being 20 the same as those for the students, only adapting the sentence the classmate with diabetes to the student with diabetes, in addition to other four questions about what to do during hyperglycemia and hypoglycemia crises.

The participants had the following answer options: yes, no, and I don't know. For the students, there were also the option to answer by pointing a corresponding picture answer, with the thumb up for yes, the thumb down for no, and both hands open and palms up for I do not know, in the case he/she did not want to verbally answer the questions.

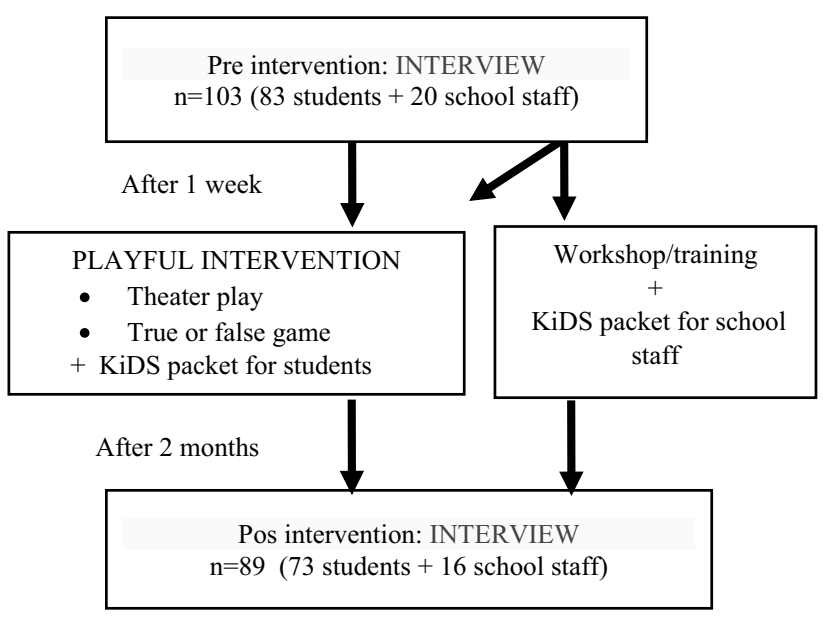

Fig. 1 Methodological path of the study 


\section{Interventions}

The playful educational interventions used with the students and the school staff were a theater play [10] and a true and false dynamic game with statements questions about diabetes inside balloons, during $40 \mathrm{~min}$. The script content of the theater play was about a T1DM student story starting in a new school, and his challenges with his classmates and teacher to do his diabetes self-care at school. There were specific scenes about the use of a glucometer, insulin shot, diet and consumption of sweets (candies), physical activity, unrestricted use of bathroom and access to drink water in times of hyperglycemia, signs and symptoms of a hypoglycemic crisis, among others.

The school staff training occurs in a workshop format with dynamics about diabetes care at school, highlighting the following topics: symptoms of hyperglycemia and hypoglycemia recognition and how to cope in these situations, diabetes kit bag, and the responsibilities and assignment of the stakeholders (parent/guardian, school staff, student) [16-18]. In addition, they had a practical workshop about glucometer uses and the results interpretation. All training lasted about an hour and a half.

The printed educational package with information about diabetes in schools, donated by ADJ Diabetes Brasil, was distributed at the end of the interventions to all present participants; in their students and school staff [15] versions, to help reinforcing the knowledge acquired during the interventions.

\section{Data analysis and ethical aspects}

The pre- and post-intervention answer comparison was analyzed using the PSPP software developed by the GNU (Gnuis Not Unix) project. The McNemar test was used to verify changes in the answers, with a significance level of $0.05 \%$. The interview answers were categorized as a dichotomous variable (yes/no) option, with the I don't know answers being considered not adequate.

The study was approved by the Ethics Committee on Human Research of the UFSB-Brazil, under CAAE number 17382619.4.0000.8467. Number of Approval: 3.609.716, September, 2019.

\section{Results}

\section{Participant profiles}

A total of 89 individuals finished the study, 73 students and 16 school staff. Among students, there were 42 (57.5\%) female and $31(42.5 \%)$ male, aged 7 to 12 years $(M=9$; $S D=1)$. Regarding the school grade, $22(30.1 \%)$ were in second grade, $24(32.9 \%)$ in third grade, $13(17.8 \%)$ in fourth grade, and $14(19.2 \%)$ in fifth grade. All school staff were female, aged 32 to 59 years $(M=45 ; S D=6)$, and with education level as follows: completed under graduation, 7 (43.7\%); completed high school, 1 (6.3\%); uncompleted high school, 6 (37.5\%); and completed primary school, 2 (12.5\%).

\section{Relationship with diabetes}

Among students, most of them, 71 (97.2\%), answered that they did not have diabetes, one had the disease but did not know the type, and other had T1DM. Additionally, 52 (71.2\%) students reported having someone with diabetes close to them, family member or friend. None school staff participant stated having diabetes, but 15 of them (93.7\%) answered that they had someone close with this condition.

\section{Pre- and post-intervention knowledge assessment}

The results of the interview questions with the students and school staff are shown in the following tables: Table 1 for diabetes general knowledge, Table 2 for diabetes signs and symptoms recognition, and Table 3 for diabetes management in the school, expressed in answers frequency and percentage, and significance level between pre- and post-intervention. The questions regarding the knowledge on behaviors and attitudes about hypoglycemia showed greater changes after the intervention.

There was a positive change in the diabetes sign and symptom recognition by the students. In the case of the school staff, adequate answers had already been given in the pre-intervention, with a significant change only for headache $(p=0.035)$.

In relation to the diabetes management in the schools, there were changes for almost all the answers among students and, for the school staff, only in those related to the correction of hypoglycemia events (Table 3).

\section{Discussion}

This study evaluated the effectiveness of a diabetes intervention in school environment, and it was able to cause important changes in the students' and the school staff's knowledge and perception, with the main changes related with hypoglycemia and sugar intake by people with diabetes.

With regard to general knowledge about diabetes, the possibility of consuming something with sugar by those with diabetes is one of the issues where the majority of the lay public and even health professionals are mistaken. In our study, after the interventions, there was a greater number of correct answers in all the questions related to this topic, both for the students and for the school staff, including the 
Table 1 Diabetes general knowledge of students $(n=73)$ and school staff $(n=16)$

\begin{tabular}{|c|c|c|c|c|c|c|c|c|}
\hline \multirow[t]{2}{*}{ Question } & & \multicolumn{3}{|c|}{ Pre-intervention } & \multicolumn{3}{|c|}{ Post-intervention } & \multirow{2}{*}{$\begin{array}{l}\text { McNemar test } \\
p \text { value }\end{array}$} \\
\hline & & Yes & No & I don't know & Yes & No & I don't know & \\
\hline \multirow{2}{*}{$\begin{array}{l}\text { Can children and adolescents have } \\
\text { diabetes? }\end{array}$} & Students & $60(82.2 \%)$ & $7(9.6 \%)$ & $6(8.2 \%)$ & $65(89 \%)$ & $6(8.2 \%)$ & $2(2.8 \%)$ & 0.133 \\
\hline & School staff & $16(100 \%)$ & 0 & 0 & $16(100 \%)$ & 0 & 0 & 0.001 \\
\hline \multirow{2}{*}{$\begin{array}{l}\text { Is diabetes contagious from one } \\
\text { person to another? }\end{array}$} & Students & $19(26 \%)$ & $40(54.8 \%)$ & $14(19.2 \%)$ & $5(6.8 \%)$ & $57(78.1 \%)$ & $11(15.1 \%)$ & 0.001 \\
\hline & School staff & $1(6.3 \%)$ & $15(93.7 \%)$ & 0 & 0 & $16(100 \%)$ & 0 & 0.5 \\
\hline \multirow[t]{2}{*}{ Is there diabetes cure? } & Students & $40(54.8 \%)$ & $18(24.7 \%)$ & $15(20.5 \%)$ & $29(39.7 \%)$ & $32(43.8 \%)$ & $12(16.5 \%)$ & 0.005 \\
\hline & School staff & $3(18.7 \%)$ & $12(75 \%)$ & $1(6.3 \%)$ & $2(12.55)$ & $13(81.2 \%)$ & $1(6.3 \%)$ & 0.5 \\
\hline \multirow[t]{2}{*}{ Is there diabetes treatment? } & Students & $57(78.1 \%)$ & $6(8.2 \%)$ & $10(13.7 \%)$ & $56(76.7 \%)$ & $6(8.2 \%)$ & $11(15.1 \%)$ & 0.5 \\
\hline & School staff & $15(93.7 \%)$ & 0 & $1(6.3 \%)$ & $16(100 \%)$ & 0 & 0 & 0.5 \\
\hline \multirow{2}{*}{$\begin{array}{l}\text { Can the person who has diabetes } \\
\text { eat sweets? }\end{array}$} & Students & $1(1.4 \%)$ & $70(95.9 \%)$ & $2(2.7 \%)$ & $33(45.2 \%)$ & $37(50.7 \%)$ & $3(4.1 \%)$ & 0.001 \\
\hline & School staff & $4(25 \%)$ & $10(62.5 \%)$ & $2(12.5 \%)$ & $12(75 \%)$ & $4(25 \%)$ & 0 & 0.011 \\
\hline \multirow{2}{*}{$\begin{array}{l}\text { Can the "blood sugar" level get to } \\
\text { low in a classmate/person with } \\
\text { diabetes? }\end{array}$} & Students & $42(57.5 \%)$ & $14(19.25)$ & $17(23.3 \%)$ & $65(89 \%)$ & $7(9.6 \%)$ & $1(1.4 \%)$ & 0.001 \\
\hline & School staff & $9(56.2 \%)$ & $1(6.3 \%)$ & $6(37.5 \%)$ & $16(100 \%)$ & 0 & 0 & 0.008 \\
\hline
\end{tabular}

Table 2 Diabetes sign and symptom recognition by students $(n=73)$ and school staff $(n=16)$

\begin{tabular}{|c|c|c|c|c|c|c|c|c|}
\hline \multirow[t]{2}{*}{ Question } & & \multicolumn{3}{|c|}{ Pre-intervention } & \multicolumn{3}{|c|}{ Post-intervention } & \multirow{2}{*}{$\begin{array}{l}\text { McNemar test } \\
p \text { value }\end{array}$} \\
\hline & & Yes & No & I don’t know & Yes & No & I don't know & \\
\hline \multirow{2}{*}{$\begin{array}{l}\text { Can a classmate/student with } \\
\text { diabetes may need to leave } \\
\text { the classroom several times } \\
\text { to pee? }\end{array}$} & Students & $35(47.9 \%)$ & $15(20.6 \%)$ & $23(31.5 \%)$ & $63(86.3 \%)$ & $8(11 \%)$ & $2(2.7 \%)$ & 0.001 \\
\hline & School staff & $15(93.7 \%)$ & 0 & $1(6.3 \%)$ & $16(100 \%)$ & 0 & 0 & 0.5 \\
\hline \multirow{2}{*}{$\begin{array}{l}\text { Can a classmate/student with } \\
\text { diabetes suddenly feel head- } \\
\text { ache? }\end{array}$} & Students & $45(61.6 \%)$ & $11(15.1 \%)$ & $17(23.3 \%)$ & $48(65.8 \%)$ & $10(13.7 \%)$ & $15(20.5 \%)$ & 0.356 \\
\hline & School staff & $8(50 \%)$ & 0 & $8(50 \%)$ & $14(87.5 \%)$ & $1(6.25 \%)$ & $1(6.25 \%)$ & 0.035 \\
\hline \multirow{2}{*}{$\begin{array}{l}\text { Can a classmate/student sud- } \\
\text { denly be very irritability? }\end{array}$} & Students & $21(28.85 \%)$ & $32(43.8 \%)$ & $20(27.4 \%)$ & $47(64.4 \%)$ & $16(21.9 \%)$ & $10(13.7 \%)$ & 0.001 \\
\hline & School staff & $7(43.7 \%)$ & $3(18.8 \%)$ & $6(37.5 \%)$ & $13(81.2 \%)$ & $2(12.5 \%)$ & $1(6.3 \%)$ & 0.688 \\
\hline \multirow{2}{*}{$\begin{array}{l}\text { Can a classmate/student with } \\
\text { diabetes suddenly feel dizzy- } \\
\text { ness? }\end{array}$} & Students & $50(68.5 \%)$ & $11(15.1 \%)$ & $12(16.4 \%)$ & $65(89 \%)$ & $5(6.9 \%)$ & $3(4.1 \%)$ & 0.001 \\
\hline & School staff & $15(93.7 \%)$ & 0 & $1(6.3 \%)$ & $16(100 \%)$ & 0 & 0 & 0.5 \\
\hline \multirow{2}{*}{$\begin{array}{l}\text { Can a classmate/student with } \\
\text { diabetes suddenly have blurry } \\
\text { vision? }\end{array}$} & Students & $33(45.2 \%)$ & $19(26 \%)$ & $21(28.8 \%)$ & $40(54.8 \%)$ & $16(21.9 \%)$ & $17(23.3 \%)$ & 0.072 \\
\hline & School staff & $14(87.5 \%)$ & 0 & $2(12.55)$ & $16(100 \%)$ & 0 & 0 & 0.25 \\
\hline \multirow{2}{*}{$\begin{array}{l}\text { Can a classmate/student with } \\
\text { diabetes pass out suddenly? }\end{array}$} & Students & $46(63 \%)$ & $14(19.2 \%)$ & $13(17.8 \%)$ & $57(78 \%)$ & $8(11 \%)$ & $8(11 \%)$ & 0.031 \\
\hline & School staff & $15(93.7 \%)$ & 0 & $1(6.3 \%)$ & $16(100 \%)$ & 0 & 0 & 0.5 \\
\hline \multirow{2}{*}{$\begin{array}{l}\text { Can a classmate/student with } \\
\text { diabetes be very sleepy during } \\
\text { class? }\end{array}$} & Students & $28(38.4 \%)$ & $25(34.2 \%)$ & $20(27.4 \%)$ & $48(65.8 \%)$ & $13(17.8 \%)$ & $12(16.4 \%)$ & 0.001 \\
\hline & School staff & $12(75 \%)$ & 0 & $4(25 \%)$ & $14(87.5 \%)$ & $1(6.25 \%)$ & $1(6.25 \%)$ & 0.312 \\
\hline
\end{tabular}

questions related to behavior and attitudes in hypoglycemia, which showed the greatest changes. In this aspect, the importance of highlighting this topic in the interventions was verified, contextualizing it, as recommended, within a healthy diet and in the case of correction of hypoglycemic crises [15].

Some studies have used theater plays as a tool to stimulate behavioral change and promote diabetes education, but mostly directed to people with diabetes [19-21]. Promoting diabetes education among school community is of value to provide support and assistance to the family and T1DM student, when it is needed, as well to stimulate prevention of obesity and T2DM. In this context, it is important to consider the substantial increase in independence and classmates behavior influences in the adolescents' life [22].

The two questions that could be related to bullying, whether diabetes is contagious from one person to another, and whether the classmate with diabetes can have a snack together with the others, also presented an increase of correct answers after the intervention among the students. These 
Table 3 Diabetes management in the school of students $(n=73)$ and school staff $(n=16)$

\begin{tabular}{|c|c|c|c|c|c|c|c|c|}
\hline \multirow[t]{2}{*}{ Question } & & \multicolumn{3}{|c|}{ Pre-intervention } & \multicolumn{3}{|c|}{ Post-intervention } & \multirow{2}{*}{$\begin{array}{l}\text { McNemar test } \\
\text { p value }\end{array}$} \\
\hline & & Yes & No & I don't know & Yes & No & I don't know & \\
\hline \multirow{2}{*}{$\begin{array}{l}\text { Can a classmate/student with dia- } \\
\text { betes need to have a different } \\
\text { snack than the other students? }\end{array}$} & Students & $61(83.6) \%$ & $6(8.2 \%)$ & $6(8.2 \%)$ & $32(43.8 \%)$ & $37(50.7 \%)$ & $4(5.5 \%)$ & 0.001 \\
\hline & School staff & $16(100 \%)$ & 0 & 0 & $12(75 \%)$ & $4(25 \%)$ & 0 & 0.062 \\
\hline \multirow{2}{*}{$\begin{array}{l}\text { Can a classmate/student with } \\
\text { diabetes dance, jump and run? }\end{array}$} & Students & $27(37 \%)$ & $24(32.9 \%)$ & $22(30.1 \%)$ & $61(83.5 \%)$ & $8(11 \%)$ & $4(5.5 \%)$ & 0.001 \\
\hline & School staff & $15(93.7 \%)$ & $1(6.3 \%)$ & 0 & $16(100 \%)$ & 0 & 0 & 0.5 \\
\hline \multirow{2}{*}{$\begin{array}{l}\text { Can a classmate/student with } \\
\text { diabetes have a snack with } \\
\text { others (in the same place and at } \\
\text { the same time)? }\end{array}$} & Students & $50(68.5 \%)$ & $15(20.5 \%)$ & $8(11 \%)$ & $63(86.3 \%)$ & $8(11 \%)$ & $2(2.7 \%)$ & 0.004 \\
\hline & School staff & $13(81.2 \%)$ & $2(12.5 \%)$ & $1(6.3 \%)$ & $15(93.7 \%)$ & $1(6.3 \%)$ & 0 & 0.25 \\
\hline \multirow{2}{*}{$\begin{array}{l}\text { From time to time, does the } \\
\text { classmate/student with diabetes } \\
\text { have to prick his finger to check } \\
\text { his diabetes? }\end{array}$} & Students & $56(76.7 \%)$ & $5(6.9 \%)$ & $12(16.4 \%)$ & $71(97.2 \%)$ & $1(1.4 \%)$ & $1(1.4 \%)$ & 0.001 \\
\hline & School staff & $15(93.75)$ & 0 & $1(6.3 \%)$ & $16(100 \%)$ & 0 & 0 & 0.5 \\
\hline \multirow{2}{*}{$\begin{array}{l}\text { Does the classmate/student have } \\
\text { to have always candies with } \\
\text { him in case he feels bad? }\end{array}$} & Students & $21(28.8 \%)$ & $42(57.5 \%)$ & $10(13.7 \%)$ & $64(87.7 \%)$ & $9(12.3 \%)$ & 0 & 0.001 \\
\hline & School staff & $4(25 \%)$ & $9(56.3 \%)$ & $3(18.7 \%)$ & $14(87.5 \%)$ & $1(6.25 \%)$ & $1(6.25 \%)$ & 0.001 \\
\hline \multirow{2}{*}{$\begin{array}{l}\text { Can a classmate/student with } \\
\text { diabetes may need an insulin } \\
\text { shot in the school? }\end{array}$} & Students & $31(42.5 \%)$ & $20(27.4 \%)$ & $22(30.1 \%)$ & $55(75.3 \%)$ & $7(9.6 \%)$ & $11(15.1 \%)$ & 0.001 \\
\hline & School staff & $12(75 \%)$ & $1(6.3 \%)$ & $3(18.7 \%)$ & $15(93.7 \%)$ & $1(6.3 \%)$ & 0 & 0.125 \\
\hline \multirow{2}{*}{$\begin{array}{l}\text { Can a classmate/student with dia- } \\
\text { betes may need to eat in differ- } \\
\text { ent times than his classmates? }\end{array}$} & Students & $28(38.4 \%)$ & $29(39.7 \%)$ & $16(21.9 \%)$ & $27(37 \%)$ & $36(49.3 \%)$ & $10(13.7 \%)$ & 0.5 \\
\hline & School staff & $14(87.5 \%)$ & $1(6.25 \%)$ & $1(6.25 \%)$ & $15(93.7 \%)$ & $1(6.3 \%)$ & 0 & 0.5 \\
\hline \multicolumn{9}{|c|}{ Questions applied exclusively to the School Staff } \\
\hline \multicolumn{2}{|c|}{$\begin{array}{l}\text { When a student with diabetes has very low } \\
\text { blood sugar (hypoglycemia), should you offer } \\
\text { him water with sugar? }\end{array}$} & $5(31.3 \%)$ & $7(43.7 \%)$ & $4(25 \%)$ & $14(87.5 \%)$ & $2(12.5 \%)$ & 0 & 0.002 \\
\hline \multicolumn{2}{|c|}{$\begin{array}{l}\text { When a student with diabetes has very low } \\
\text { blood sugar (hypoglycemia), should you offer } \\
\text { him candies or sweets? }\end{array}$} & $3(18.75 \%)$ & $10(62.5 \%)$ & $3(18.75 \%)$ & $12(75 \%)$ & $3(18.7 \%)$ & $1(6.3 \%)$ & 0.002 \\
\hline \multicolumn{2}{|c|}{$\begin{array}{l}\text { When a student with diabetes gets very high } \\
\text { blood sugar (hyperglycemia), does he need an } \\
\text { insulin shot right away? }\end{array}$} & $7(43.8 \%)$ & $3(18.7 \%)$ & $6(37.5 \%)$ & $10(62.5 \%)$ & $1(6.3 \%)$ & $5(31.2 \%)$ & 0.227 \\
\hline \multicolumn{2}{|c|}{$\begin{array}{l}\text { When a student with diabetes gets very low } \\
\text { blood sugar (hypoglycemia), can he die if he } \\
\text { doesn't have help quickly? }\end{array}$} & $10(62.5 \%)$ & $1(6.3 \%)$ & $5(31.2 \%)$ & $15(93.7 \%)$ & $1(6.3 \%)$ & 0 & 0.063 \\
\hline
\end{tabular}

findings are important since episodes/behaviors of exclusion and/or segregation are frequently reported by children and adolescents with diabetes [6], especially at school [23, 24].

There was a significant recognition of the insulin shot necessity at school, as part of diabetes management, by the interviewed students. However, there was one staff school participant who still negatively answered about this subject after the training. This is other important subject in diabetes education, since unfortunately there are reports from people with diabetes (personal communication) that it has been mistaken for an illicit drug user while inject insulin with a syringe [25].

A number of studies have pointed out the children and adolescents with T1DM get shamed and embarrassed when measuring their blood glucose and inject insulin, both in and out of the schools [23, 26], especially with the use of a syringe or infusion pump, aggravating social stigma [23]. The use of insulin in multiple doses per day has been recognized already for some years as an efficient treatment in T1DM; therefore, there is often a need for at least one application at school, especially before eating [15, 18].

Another important result was acknowledging that the classmate with diabetes can practice physical and recreational activities. This understanding assists in the proper management of diabetes, since physical activity is an important part of the treatment [15, 27].

Not recognizing the main signs and symptoms in diabetes, both in hyperglycemia and hypoglycemia events, is admittedly another obstacle in social life [23, 26, 28]. This issue was highlighted in the theater play. Although these symptoms are very individualized, polyuria and polydipsia were highlighted for hyperglycemia, and weakness fatigue, 
drowsiness, hunger, blurry vision, sweating, shakiness, dizziness, fast heartbeat, and fainting (when more severe) in hypoglycemia. Thus, only for the questions about headache and blurry vision, no differences were verified after the intervention among the interviewed students.

Learning how to acknowledge hyperglycemia symptoms is very important at the school environment. It can make a way for an early diabetes screening, often avoiding the sudden onset of T1DM in a severe and traumatic way such as ketoacidosis [29].

There was also a significant increase in the recognition of mood changes, irritability, by the students after the intervention. This finding is important because it facilitates support and reception of students with diabetes by their classmates during a glycemic imbalance, which can occur both in hypoglycemia [15, 30] and in hyperglycemia [15].

Understanding why students with T1DM may need to eat at different times is important to avoid discrimination and facilitate management in the school environment. This sometimes should happen to prevent hypoglycemic crisis, and the most common reasons which it can occur are as follows: prolonged fasting status, skipped missed or delayed meals/snacks, unfinished meals (for little kids), too much insulin on board, too little carbohydrate, unplanned exercise and activities [15, 22, 30-32].

Thus, generally when blood glucose is below $90 \mathrm{~mL} / \mathrm{dL}$ and/or dropping, for those who use glucose sensor with trend arrows, and the next meal will be in a long time or the person will have a physical exercise, it is suggested to eat a small snack $[22,27]$.

The questions related to how to cope in a hypoglycemic crisis stood out among the most relevant results after the intervention for the school staff. It was acknowledged that offering something with sugar is important to revert the situation. It has been established that $15 \mathrm{~g}$ of quick-acting carbohydrate must be ingested at these moments [22,31], unless loss of conscious happens [15].

Other important aspects of the diabetes care at school were highlighted for the school staff, including the encouragement of students with diabetes to have always with them the diabetes kit bag, which included 15 or $30 \mathrm{~g}$ of fast-absorbing carbohydrate and an extra snack to correct or prevent a hypoglycemia event, glucometer, and insulin, in addition to the relevant supplies, such as reagent strips for measuring glucose and syringe or pen for insulin application $[13,15,18]$. And also, it has at school the update personal diabetes management plan for each student with diabetes, where is written down all details of his/her treatment [15].

One strength of our study was to use the KiDS educational package, a validate material from International Diabetes Federation. Other strength was to work diabetes education with all school employee categories, plus the majority of students enrolled, encouraging a healthy lifestyle and reducing bullying about self-care diabetes. Thus, we stimulate the replicability of the methodology used to other schools, not only in Brazil but also in other countries, in order to better disseminate issues related to the management of T1DM within the school environment.

A limitation of this study was to conduct it only in one school, due to the restrictions resulting from the COVID19 pandemic, with just 16 school staff finishing the postintervention interview, thus limiting generalization of the results. Also, a longer additional interview, 6 or 9 months later, could give information about the long-term memory or impact of the intervention.

\section{Conclusion}

The educational intervention, with the use of the theater play, playful games, KiDS educational package, and workshop training, was effective in changing the students' and school staff's knowledge and perception, especially about the main changes related with hypoglycemia and sugar intake by people with diabetes, and can be used as a methodology for diabetes education. These actions contributed to stimulating the children and adolescents to become replicators of the knowledge acquired about diabetes in the school environment.

Funding This study was supported by the Federal University of Southern Bahia (BRAZIL)- PROPPG/UFSB $N^{\circ}$ 08/2020 and ID:23746.005146/2020-91.

Data availability Not applicable for that section.

Code availability Not applicable for that section.

\section{Declarations}

Ethical approval Ethical approval to report this study was obtained from the Federal University of Southern Bahia ETHICS COMMITTEE'S (APPROVAL NUMBER 3.609.716./CAAE: 17382619.4.0000.8467).

Statement of human All procedures in this study were conducted in accordance with the Federal University of Southern Bahia ETHICS COMMITTEE'S (APPROVAL NUMBER 3.609.716./CAAE: 17382619.4.0000.8467).

Statement of informed consent Written informed consent was obtained from the subjects for their anonymized information to be published in this article.

Consent for publication Not applicable as this contains only de-identified information.

Conflict of interest The authors declare no competing interests. 


\section{References}

1. International Diabetes Federation. IDF diabetes atlas [Internet]. 9th ed. 2019. Available from www.diabetesatlas.org. Accessed 2 Mai 2021

2. Aldekhayel G. An assessment of the diabetic knowledge, attitude, and practice of school teachers in Riyadh, Kingdom of Saudi Arabia. J Diabetes Mellit. 2020;10(03):132-53.

3. Almohaileb FI, Alturki OA, Alsudays AM, Aldakheel IA, Alarfaj AA. Assessment of the knowledge and practices about diabetes mellitus among governmental school teachers in Uglat Asugour, Qassim, Saudi Arabia. Int J Innov Res Med Sci. 2020;5(01):31-40.

4. Bechara GM, Castelo Branco F, Rodrigues AL, Chinnici D, Chaney D, et al. "KiDS and diabetes in schools" project: experience with an international educational intervention among parents and school professionals. Pediatr Diabetes. 2018;19(4):1-5.

5. Smith LB, Terry A, Bollepalli S, Rechenberg K. School-based management of pediatric type 1 diabetes: recommendations, advances, and gaps in knowledge. Curr Diab Rep. 2019;19(7):16. Available from https://link.springer.com/article/https://doi. org/10.1007/s11892-019-1158-x. Accessed 5 Mai 2021.

6. Andrade CJ do N, Alves C de AD. Relationship between bullying and type 1 diabetes mellitus in children and adolescents: a systematic review. J Pediatr (Rio J). 2019;95(5):509-18. Available from: https://doi.org/10.1016/j.jpedp.2018.10.006. Accessed 5 Mai 2021.

7. International Diabetes Federation. Kids and diabetes in school [Internet]. International Diabetes Federation. 2019. Available from https://kids.idf.org/. Accessed 5 Mai 2021.

8. dos Reis APG, Souza ALV, de Lovato AC, da Silva AH, Guimarães DB, et al. Implementation of the diabetes reference center at schools in Minas Gerais. Diabetol Metab Syndr. 2018;10(Supp 1):A214.

9. Silva Júnior $\mathrm{H}$ dos $\mathrm{S}$, Martins VP de A, Cunha MD, Toledo MM, Lourenço T de J, Chaves AC, et al. Implementation of a diabetes reference center in schools in Minas Gerais. In: Silva E da, editor. Extensão Universitária nas Ciências da Saúde no Brasil. 1st ed. Ponta Grossa: Atena; 2020;1-16. Available from https://www.finersistemas.com/atenaeditora/index.php/admin/ api/artigoPDF/30888. Accessed 5 Mai 2021.

10. Sedlmaier BMG, Mourão DM, Borges GF. Theater play on health education: the experience of the diabetes schools reference center team in Teixeira de Freitas/BA. In: Práticas Educativas em Saúde para pessoas com Diabetes Tipo 1. 1.ed. Curitiba: Brasil Publishing; 2020;32-47. Available from https://aeditora. com.br/produto/praticas-educativas-em-saude-para-pessoascom-diabetes-tipo-1/. Accessed 5 Mai 2021.

11. Benevides JF, de Neri DFM. A diabetes e o teatro: relato de experiência. EXTRAMUROS-Revista de Extensão da Univasf. 2015;3(1):17-21

12. Bohn R, Ghellar C, de Oliveira TB, de Kratz CP. Theatre as a tool for health education with focus on diabetes mellitus at district schools in Santo Ângelo, RS. Ensino Ciências e Tecnol em Rev. 2015;5(2):1-9.

13. Educators AA of D. Management of children with diabetes in the school setting. Diabetes Educ. 2019;45(1):54-9. Available from https://journals.sagepub.com/doi/abs/https://doi.org/10. 1177/0145721718820943. Accessed 5 Mai 2021.

14. Sociedade Brasileira de Diabetes. Diretrizes da Sociedade Brasileira de Diabetes 2019-2020. São Paulo. 2019. Available from: https://www.diabetes.org.br/profissionais/images/DIRET RIZES-COMPLETA-2019-2020.pdf. Accessed 5 Mai 2021.
15. Sociedade Brasileira de Diabetes. Projeto Kids [Internet]. Sociedade Brasileira de Diabetes. 2019. Available from https://www. diabetes.org.br/profissionais/projeto-kids. Accessed 5 Mai 2021.

16. International Diabetes Federation. Pacote educativo 1: Equipe das escolas [Internet]. Pacote Educativo para Informar sobre Diabetes nas Escolas. 2019. p. 1-38. [cited 2021 Mai 6]. Available from: https://www.diabetes.org.br/profissionais/images/Pacote_educa tivo_1_-Equipe_da_escola.pdf

17. International Diabetes Federation. Pacote Educativo 3: para Alunos [Internet]. Pacote Educativo para Informar sobre Diabetes nas Escolas. 2019. p. 1-16. [cited 2021 Mai 6]. Available from: https://www.diabetes.org.br/profissionais/images/Pacote_Educa tivo_3_-Alunos.pdf

18. Jackson CC, Albanese-O'neill A, Butler KL, Chiang JL, Deeb LC, et al. Diabetes care in the school setting: a position statement of the American Diabetes Association. Diabetes Care. 2015;38(10):1958-63.

19. Pieper CM, Costa SM, Wiltgen A, Martins A, Kupfer R. "Education with art": diabetes education through theater. Diabetol Metab Syndr. 2015;7(1):A188.

20. Szmedra P, Chand A, Prasad M, DeTitta T, Rozmus C. Using community theater to improve diabetes education in Fiji. Int $\mathrm{J}$ Diabetes Dev Ctries. 2018;38(4):502-8.

21. Kupper F, Peters LWH, Stuijfzand SM, den Besten HAA, van Kesteren NMC. Usefulness of image theater workshops for exploring dilemmas in diabetes self-management among adolescents. Glob Qual Nurs Res. 2018;5:1-10.

22. Ergun-Longmire B, Clemente E, Vining-Maravolo P, Roberts C, Buth K, et al. Diabetes education in pediatrics: how to survive diabetes. Disease-a-Month. 2021;2:1-51. Available from https:// pubmed.ncbi.nlm.nih.gov/33541707/. Accessed 5 Mai 2021.

23. Crespo-Ramos G, Cumba-Avilés E, Quiles-Jiménez M. “They called me a terrorist": social and internalized stigma in latino youth with type 1 diabetes. Heal Psychol Rep. 2018;6(4):30720. Available from: https://www.ncbi.nlm.nih.gov/pmc/articles/ PMC6481952/. Accessed 8 Mai 2021.

24. Rankin D, Harden J, Barnard KD, Stephen J, Kumar S, et al. Preadolescent children's experiences of receiving diabetes- related support from friends and peers: a qualitative study. Heal Expect. 2018;21(5):870-7. Available from http://doi.wiley.com/https:// doi.org/10.1111/hex.12802. Accessed 8 Mai 2021.

25. Browne JL, Ventura A, Mosely K, Speight J. "I'm not a druggie, I'm just a diabetic": a qualitative study of stigma from the perspective of adults with type 1 diabetes. BMJ Open. 2014;4:1-10.

26. Arns-Neumann C, Harumi Tabushi C, Araújo PorchatLeão A, Kapp Fritz C, Cristina de Souza Silva A, et al. Behavior of children and adolescents with type 1 diabetes mellitus in the school environment. Jornal Paranaense de Pediatria. 2020;21(2):1-6.

27. Colberg SR, Sigal RJ, Yardley JE, Riddell MC, Dunstan DW, Dempsey PC, et al. Physical activity/exercise and diabetes: a position statement of the American Diabetes Association. Diabetes Care. 2016;39(11):2065-79.

28. Schabert J, Browne JL, Mosely K, Speight J. Social stigma in diabetes: a framework to understand a growing problem for an increasing epidemic. Patient. 2013;6(1):1-10. Available from: http://link.springer.com/https://doi.org/10.1007/s40271-0120001-0. Accessed 12 Mai 2021.

29. de Souza LCVF, de Kraemer GC, Koliski A, Carreiro JE, Cat MNL, et al. Diabetic ketoacidosis as the initial presentation of type 1 diabetes in children and adolescents: epidemiological study in southern Brazil. Rev Paul Pediatr. 2020;38:e2018204.

30. Law JR, Yeşiltepe-Mutlu G, Helms S, Meyer E, Özsu E, et al. Adolescents with type 1 diabetes mellitus experience 
psychosensorial symptoms during hypoglycaemia. Diabet Med. 2014;31(10):1245-51. Available from: https://pubmed.ncbi.nlm. nih.gov/24965522/. Accessed 12 Mai 2021.

31. Ortiz MR. Hypoglycemia in diabetes. Nurs Clin. 2017;52(4):56574. Available from: https://www.nursing.theclinics.com/article/ S0029-6465(17)30082-8/abstract. Accessed 12 Mai 2021.

32. Chinnici D, Middlehurst A, Tandon N, Arora M, Belton A, Reis $\mathrm{D}$, et al. Improving the school experience of children with diabetes: evaluation of the KiDS project. J Clin Transl Endocrinol.
2019;15:70-5. Available from: https://doi.org/10.1016/j.jcte.2018. 12.001. Accessed 5 Mai 2021.

Publisher's note Springer Nature remains neutral with regard to jurisdictional claims in published maps and institutional affiliations. 